\title{
Carbonated Soft Drinks and Orthodontics: Review of Literature
}

\author{
Zainab A. Abd Al-Hussain' (iD, Mohammed Nahidh²
}

'Dentist, Ministry of Health, Baghdad, Iraq

2Department of Orthodontics, University of Baghdad, Faculty of Dentistry, Baghdad, Iraq

Cite this article as: Abd Al-Hussain ZA, Nahidh M. Carbonated Soft Drinks and Orthodontics: Review of Literature. Turk J Orthod. $2021 ; 34(2)$ : $136-142$.

Main points:

Increased consumption of carbonated soft drinks has harmful effects on bone metabolism.

Tooth movement is greatly affected by the increased carbonated soft drinks consumption.

Shear bond strength, enamel surface, color stability, corrosion, and surface changes of different materials are greatly affected by the carbonated soft drinks.

\begin{abstract}
This study aims to review the effects of various types of carbonated soft drinks on the behavior of different orthodontic materials as well as on the enamel surface and tooth movement. Articles and books from 1990 to 2020 explaining the effects of carbonated soft drinks on general health and orthodontic materials and tooth movement were electronically searched. The major effects of carbonated soft drinks are explained and discussed in this review. Patients with orthodontic problems must be warned about the side effects of carbonated soft drinks on general and dental health and orthodontic appliances in particular.
\end{abstract}

Keywords: Carbonated soft drinks, corrosion, elastic force decay, orthodontics, shear bond strength

\section{INTRODUCTION}

Carbonated soft drinks consumption has become a greatly perceptible and contentious public health and policy matter. They are considered as a chief contributor to obesity and associated with well-being tribulations by many, mostly among children. ${ }^{1}$

Numerous fitness problems are allied with ordinary utilization of carbonated soft drinks, but their effects on the health are unclear although epidemiological studies point toward their relationship with obesity, kidney disease, liver disease, and dental and bone problems. ${ }^{2}$

Carbonated soft drinks predominantly contain water, phosphoric acid, citric acid, caffeine, sugar (for example, sucrose) and other chemicals in the form of acid regulators, carbon dioxide, preservatives, colorings, and flavors. ${ }^{3}$ Carbonated beverages are prepared by mixing flavored syrup with carbonated water, both of which are chilled. There are different types of carbonated beverages, including colas, energy and sports drinks, functional beverages, and low- and mid-calorie beverages. ${ }^{4}$

Different studies have shown that carbonated soft drinks can affect the rate of tooth movement and properties of various orthodontic materials; therefore, a comprehensive review of these studies is required. This study aimed to review the effects of diverse types of carbonated soft drinks on the behavior of different orthodontic materials as well as on the enamel surface and tooth movement. 


\section{Effects of Carbonated Soft Drinks}

\section{Effects on Health}

In their systematic review and meta-analysis, Vartanian et al. ${ }^{5}$ reviewed 88 articles and reported that in many studies, a positive association was reported between increased consumption of carbonated soft drinks and energy intake, increased body weight and body-mass index, increased carbohydrate intake, and many negative health problems, such as type II diabetes, hypocalcemia, tendency of bone fracture, reduced bone mineral density, increased blood pressure and various cardiovascular diseases, kidney and liver diseases, tooth erosion, and increased vulnerability to dental caries.

\section{Effects on the Tooth Movement}

The effects of some carbonated soft drinks on the rate of tooth movement in rats were evaluated by Aghili et al. ${ }^{6}$ They gave the rats Fanta ${ }^{\circledR}$ and Coca-Cola ${ }^{\circledast}$ for 2 weeks before orthodontic appliance placement. A force of about $60 \mathrm{gm}$ was exerted through a $5-\mathrm{mm} \mathrm{NiTi} \mathrm{coil} \mathrm{spring} \mathrm{ligated} \mathrm{between} \mathrm{the} \mathrm{right} \mathrm{incisor} \mathrm{and} \mathrm{first}$ molar for 2 weeks.The amount of orthodontic tooth movement between the maxillary first and second molars was then measured using an interproximal filler gauge. Their findings indicated that the rate of tooth movement decreased in the experimental groups than in the control group, being more with Fanta ${ }^{\circledR}$ than Coca-Cola ${ }^{\circledR}$.

The possible explanations for these findings are discussed according to the drinks' components, such as sugar, citric acid, phosphoric acid, caffeine, and other additives.

Calvo ${ }^{7}$ found that high phosphorus intake was shown to cause bone loss in animals; however, Amato et al. ${ }^{2}$ concluded that Coca-Cola ${ }^{\circledR}$ intake causes significant hypercalciuria and hyper phosphaturia in immature and adult rats. The older animals also developed hyperparathyroidism.

Theoretically, diets that are high in phosphate and low in calcium lead to a decreased serum level of calcium and a provoking complex for parathyroid hormone, leading to decalcification of the bones and re-establishment of calcium homeostasis in the body, but the amount of phosphoric acid present in Coca-Cola ${ }^{\circledR}$ is not sufficient to cause this. ${ }^{8}$

Paldánius et al. ${ }^{9}$ reported that high oral intake of glucose can lead to a rapid, statistically significant decrease in bone formation, resorption markers, and carboxylated-type serum osteocalcin.

The acid loads may also affect the bone content and metabolism. Lee et al. ${ }^{10}$ found that acidemia will increase the bone degeneration and calcium release and decrease the activity of 1a-hydroxylase and production of 1a,25-dihydroxyvitamin D. ${ }^{11}$ However, Amato et al. ${ }^{2}$ found that high consumption of $\mathrm{Coca}-\mathrm{Cola}^{\circledR}$ causes acidosis in immature rats.

The tested drinks contain acidic components (such as carbon dioxide and phosphoric acid in Coca-Cola ${ }^{\circledR}$ and citric acid in Fan$\mathrm{ta}^{\oplus}$ ) that may alter bone metabolism toward this condition. This may influence the bone remodeling process and subsequent orthodontic tooth movements.

Caffeine, as an additive in some drinks, especially cola, may also lead to excretion of calcium in urine, a condition known as calciuria. $^{12}$

Wink et al. ${ }^{13}$ showed that growing rats that received caffeine had significant histological differences, such as fewer osteocytes per femoral cross-section area, impaired structural remodeling of osteoblasts, and osteocytes with disrupted swollen mitochondria, compared with the control group.

Shirazi et al. ${ }^{14}$ studied the effect of different doses of caffeine on orthodontic tooth movement in rats and found that with increasing caffeine dosage, the orthodontic tooth movement and bone resorption were significantly decreased. However, the ultimate effects of caffeine on the bone and calcium economy in human beings depend on other factors, mainly calcium intake from the diet, and the net effects are controversial.

\section{Effect on the Shear Bond Strength}

Önçağ et al. ${ }^{15}$ determined the effects of Coca-Cola ${ }^{\circledR}$ and Sprite ${ }^{\circledast}$ on the shear bond strength of metal orthodontic brackets bonded to human teeth both in vitro and in-vivo; the findings proved a significant decrease in shear bond strength in both groups in comparison with artificial saliva as they thermocycled the bonded teeth, and thermocycling proved to decrease the bond strength by $20 \%$ to $70 \%$. Using a scanning electron microscope (SEM), the areas of defect on the enamel surface around the brackets were observed in both groups owing to the erosive effect of these soft drinks.

Navarro et al. $^{16}$ studied the influence of Coca-Cola ${ }^{\circledR}$ and Schweppes Limón ${ }^{\circledast}$ on bond strength, adhesive remnants, and microleakage in stainless-steel brackets of maxillary incisors bonded to bovine teeth. They found that these drinks caused enamel erosion, loss of adhesive material, and microleakage but had no significant effect on the shear bond strength of the brackets or adhesive remnants.

Khoda et al. ${ }^{17}$ evaluated the effects of a carbonated yogurt drink with a lactic acid base, 7-Up ${ }^{\circledR}$ and Pepsi-Cola ${ }^{\circledR}$, on the shear bond strength of stainless-steel brackets. They concluded that these soft drinks did not decrease the shear bond strength significantly compared with artificial saliva, similar to the study by Navarro et al. ${ }^{16}$

Hammad and Enan ${ }^{18}$ evaluated the effect of 2 brands of acidic soft drinks (Coca-Cola ${ }^{\circledR}$ and Sprite ${ }^{\circledast}$ ) on the shear bond strength of metal brackets with and without resin infiltration treatment and assessed the enamel surface after debonding using SEM. They found that groups without resin infiltration demonstrated lower resistance to the shear forces. According to the findings of SEM, both groups after resin application showed a significant improvement compared with the results without resin use, as the enamel appeared smoother and less erosive. 
Nahidh ${ }^{19}$ studied the effect of One Tiger ${ }^{\circledR}$ (a carbonated energy drink) on the shear bond strength and site of bond failure of stainless-steel bracket to human teeth. He found that One Tiger ${ }^{\circledR}$ reduced the shear bond strength significantly below the acceptable limit.

Pasha et al. ${ }^{20}$ assessed the effect of Coca-Cola ${ }^{\circledR}$ and orange Miranda $^{\circledR}$ on the shear bond strength and site of bond failure in stainless-steel brackets bonded to intact human teeth; an SEM evaluation of the intact and sealed enamel was also performed. The results indicated that the shear bond strength was decreased significantly by both beverages, and this effect was stronger in orange Miranda ${ }^{\circledR}$ with greater adhesive failure at the site of bond failure. SEM results indicated a greater presence of defective areas because of erosion caused by acidic soft drinks on intact and sealed enamel surfaces in Coca-Cola ${ }^{\circledR}$ than in orange Miranda ${ }^{\circledR}$.

In general, carbonated soft drinks can affect shear bond strength in 2 ways: by deteriorating the structure of the adhesive materials and by causing erosive lesions on the enamel surface around the brackets, with the main effect of the beverage compositions and total acid content, rather than beverage $\mathrm{pH}$, determining the actual aggression toward the enamel. ${ }^{15,20}$ Regarding the beverage matrix, there are additional composite interactions between the soluble and solid contents of a beverage, such as the acid/hydroxyapatite reaction, which yet again influences the impending erosion. ${ }^{21}$

The type of acid has also an effect on the severity of erosion. SEM comparison between Coca-Cola ${ }^{\circledast}$ and Sprite $^{\circledR}$ groups indicated more extensive and noticeable enamel defects in the Coca-Cola ${ }^{\circledR}$ group because of the enamel-erosive effect of the phosphoric acid present in Coca-Cola ${ }^{\circledR}{ }^{15}$

The erosive potential of a citric-acid-based orange juice drink and a phosphoric-acid-based diet cola drink was studied by Rugg-Gunn et al. ${ }^{21}$ They concluded that erosive potential of the phosphoric-acid-based diet cola was more than that of the citric-acid-based orange juice drink. Pasha et al. ${ }^{20}$ confirmed the previous findings but reported lower shear bond strength with citric-acid-based drinks (orange Miranda ${ }^{\circledR}$ ).

Waterhouse et al. ${ }^{22}$ confirmed that low doses of citrate can increase the $\mathrm{pH}$ and hence decrease dental plaque acidogenicity and suggested that it be added to non-alcoholic soft drinks to decrease their carcinogenicity.

The One Tiger $^{\circledast}$ energy drink contains citric acid, benzoic acid, taurine, caffeine, and carbonated water that cause enamel demineralization around the brackets. ${ }^{15}$ This could be clarified by the high concentration of refined carbohydrates that encourage greater degrees of acid production. Moreover, citric acid and citrate can bind to calcium in the tooth, maintaining a low $\mathrm{pH}$ for a long time.

Studies have found that high acidity may act as a plasticizer that speeds up the water sorption rate by reducing the polymer interchain interactions. Degradation of the composite that leads to decrease in its mechanical properties has been proved to be caused by acidic $\mathrm{pH}$ solutions ${ }^{23}$, which in turn may offer an adequate concentration of protonated protons to induce hydrolysis of the ester part found in the resin matrix. ${ }^{24}$

\section{Effects on Chemical Properties, Corrosion Resistance, and Surface Topography}

Shahabi et al..$^{25}$ studied the effect of Coca-Cola ${ }^{\circledR}$ on the corrosion of stainless-steel brackets in vitro. The brackets were weighted and immersed in Coca-Cola ${ }^{\circledR}$ at $37^{\circ} \mathrm{C}$ and in artificial saliva (control) for 6 weeks and re-weighted. The authors found that powerful corrosion took place after exposure to Coca-Cola ${ }^{\circledR}$ starting from the $1^{\text {st }}$ week and continued at a fast and almost constant rate. This can be attributed to the presence of soluble carbonic acid in Coca-Cola ${ }^{\oplus}$, an acidic solution with a relatively low $\mathrm{pH}$ that easily dissolves the protective oxide layer and makes corrosion take place faster and sooner, and the presence of small and ample carbon dioxide gas bubbles dissolved in Coca-Cola ${ }^{\circledR}$ and their adhesion to different bracket surfaces and very small but abundant pointed corrosions formed on them simultaneously. These corrosion sites developed gradually and adjoined, causing a large destruction in a limited time.

Parentiet al. ${ }^{26}$ investigated the effect of Coca-Cola ${ }^{\circledR}$ and Gatorade $^{\circledR}$ on the physical and chemical properties of $0.019 \times 0.025$ inch heat-activated NiTi orthodontic archwire. The wires were soaked in $10 \mathrm{~mL}$ of the drink for 60 minutes. They found statistically non-significant differences in terms of the Young's modulus, hardness, surface color change, topography, or chemical composition. They deduced that degradation of NiTi wires would not be caused by consumption of soft drinks.

Abalos et al. ${ }^{27}$ evaluated the effect of soft drinks on the surface topography and corrosion behaviors of $0.016 \times 0.022$-inch NiTi archwires. Different surface patterns of NiTi archwires, such as smooth, scratch, dimple, and crack, were selected and characterized using SEM and laser confocal microscopy. The archwires were immersed in a soft drink with a $\mathrm{pH}$ of 2.5 for a period corresponding 28 days, and the results were compared to archwires immersed in artificial saliva with a $\mathrm{pH}$ of 6.7. They found an increase in surface defects and/or roughness with reduction in corrosion resistance in the dimple, crack, and scratch patterns. Moreover, the surface pattern had a direct correlation with the extent of corrosion with low-pH soft drinks.

Mikulewicz et al. ${ }^{28}$ assessed the ions released (using multi-elemental inductively coupled plasma optical emission spectrometry) from a fixed orthodontic appliance after altered immersion in Coca-Cola ${ }^{\circledR}(5.5$ h) and artificial saliva (18.5 h) using a continuous flow system specially designed for their in vitro study. The appliance included 20 brackets, 4 molar bands, and two $0.017 \times 0.025$-inch archwires, all manufactured from stainless steel. The duration of the experiment was 28 days. Compared with artificial saliva, $\mathrm{Coca}-\mathrm{Cola}^{\circledR}$ intensified the release of $\mathrm{Fe}^{2+}$ ions (18 times), Mn ions (47 times), Mo ions (15 times), and Cd ions (5.6 times).However, the released $\mathrm{Cr}$ and $\mathrm{Cu}$ ions were lower than those released from artificial saliva. Moreover, the Coca-Cola ${ }^{\circledR}$ environment facilitated solubilization of $\mathrm{Ni}$ ions from the 
stainless-steel alloys. All the released ion levels were below the daily recommended doses. Orthodontic appliances present in the oral cavity undergo rapid dissolution of the surface oxide layer of the metal when exposed to the aggressive action of low-pH acidic food and drink because of thermodynamic instability and release of $\mathrm{Fe}, \mathrm{Zn}, \mathrm{Ag}, \mathrm{Ni}$, and $\mathrm{Cr}$ ions until equilibrium is reached or impedance occurs. This also results in surface dissolution of ceramic materials, pitting corrosion, and surface roughness. Released cytotoxic elements can produce discoloration in the adjacent soft tissues and allergic reactions in susceptible patients. ${ }^{29}$

Nanjundan and Vimala ${ }^{30}$ studied the in vitro effect of Pepsi-Co$\mathrm{la}^{\circledR}$ on the frictional resistance and surface characteristics of $0.019 \times 0.025$-inch stainless-steel archwires ligated to stainless-steel and polycrystalline orthodontic brackets. The archwire-bracket assemblies were immersed in Pepsi-Cola ${ }^{\circledR}$ for 24 hours and then washed, dried, and tested. The results revealed a significant increase in the surface roughness of the archwires and brackets with different degrees of pitting and surface irregularities, especially with polycrystalline brackets. Moreover, the static and kinetic frictional forces were significantly affected by Pepsi-Cola ${ }^{\circledR}$. Brackets and archwires immersed in a highly acidic Pepsi-Cola ${ }^{\circledR}$ with a pH of 2.46 showed more surface irregularities, pitting, breakdown, debris, and roughness and had the highest static and kinetic frictional forces. This is owing to the acidic ingredients that promote corrosion and breakdown. As acidity increases, the tendency toward breakdown and surface roughness of orthodontic appliances increases as well. ${ }^{31}$

Coca-Cola ${ }^{\circledast}$ contains very high levels of sugar with a low $\mathrm{pH}$ (2.465). The cathodic reaction of corrosion can be intensified by the low $\mathrm{pH}$. The suggested mechanism entails the formation of a passive layer of oxides at first and then its dissolution by the action of protons in acidic $\mathrm{pH}$, resulting in the release of metal ions. ${ }^{32}$

\section{Effects on the Color Stability of Clear Retainers, Esthetic Brackets, and Elastics}

Lew $^{33}$ determined the in vitro susceptibility of clear elastomeric modules to staining from Coca-Cola ${ }^{\circledR}$ at 6, 12, 24, 36, 48, and 72 hours using a visual analog scale (VAS). He found that Coca-Cola ${ }^{\circledR}$ produced no staining even after 72 hours.

Al-Huwaizi and Kalhan ${ }^{34}$ evaluated the effect of Coca-Cola ${ }^{\circledR}$ and Miranda ${ }^{\circledR}$ on the stainability of clear overlay retainers made from 3 types of thermoplastic materials (Duran, Clear, and Comfort) using a computerized spectrophotometer. They found that Coca-Cola ${ }^{\circledR}$ had a greater staining effect than Miranda ${ }^{\circledR}$ for all types of materials, with Comfort being the least affected and Duran being the most affected.

Ardeshna and Vaidyanathan ${ }^{35}$ assessed the color stability of colored and clear orthodontic elastomeric modules from different manufacturers soaked in Coca-Cola ${ }^{\circledR}$ for 72 hours using a Minolta chromameter. They found that Cola-Cola ${ }^{\circledR}$ caused minimal color change.

Silva et al. ${ }^{36}$ appraised the color stability of 5 different esthetic orthodontic elastic ligatures immersed in Coca-Cola ${ }^{\circledR}$ using an ultraviolet (UV)-visible spectrophotometer. They found that Coca-Cola ${ }^{\circledR}$ caused some color change in the esthetic elastic ligatures with significant differences among the different brands.

Aldrees et al. ${ }^{37}$ evaluated the amount of discoloration in clear and semi-clear elastomeric chains from 8 manufacturers using a spectrophotometer after immersion in Pepsi-Cola ${ }^{\circledR}$ for 72 hours. They found that semi-clear elastic chains tend to present significantly less discoloration than their clear counterparts.

Guignone et al. ${ }^{38}$ assessed the color stability of 5 types of ceramic brackets after immersion in Coca-Cola ${ }^{\circledR}$ for $1,3,7$, and 14 days using a UV-visible spectrophotometer. They found that despite presenting the lowest $\mathrm{pH}$ level, Coca-Cola ${ }^{\circledR}$ did not cause as much color alteration. They attributed the minimal effect of Coca-Cola ${ }^{\circledR}$ to the lack of yellow pigment in its composition.

Albo Hassan and Ghaib $^{39}$ used a UV-visible spectrophotometer to compare the stainability of sapphire ceramic brackets bonded with 3 types of light-cured orthodontic adhesives immersed in Pepsi-Cola ${ }^{\circledR}$ for 1,7 , and 14 days. They found that the brackets and adhesives underwent discoloration from Pepsi-Cola ${ }^{\circledR}$ that increased gradually until day 14 . They found that the brand, immersing solution, and storage time might influence the degree of color change in the materials. The amount of fillers present and the resin matrix of the studied adhesives played important roles in the color stability and water sorption rate of the composites. It has been shown that Pepsi-Cola ${ }^{\circledR}$ contains approximately 32-39 mg of caffeine (which is less than that in tea) as well as carbonated water (soda), phosphoric acid, and citric acid that may have some cleaning action.

Talic and Almudhi ${ }^{40}$ compared the stain resistance of 3 types of clear elastomeric modules exposed to Coca-Cola ${ }^{\circledR}$ for 72 hours through assessment by a group of dentists' perceptions of discoloration using a VAS. The study showed that Coca-Cola ${ }^{\circledR}$ caused staining in the tested modules, unlike reported previously that $\mathrm{Coca}-\mathrm{Cola}^{\circledR}$ did not produce any staining. The difference between this study and previous studies was that the previous studies examined elastomeric modules from one company, whereas this study tested elastomeric modules from 3 different companies.

Noori and Ghaib ${ }^{41}$ assessed the color stability of different types of esthetic archwires from 4 different companies after immersion in Pepsi-Cola ${ }^{\circledR}$ for 7, 14, and 21 days using a spectrophotometer. They found that Pepsi-Cola ${ }^{\circledR}$ had a weaker staining effect on the esthetic archwires. This might be related to the chemical and physical compositions of the esthetic arch wires, and the need for further study was suggested to investigate each company's products to identify the cause of this variation.

Mahmood ${ }^{42}$ evaluated the degree of color change of epoxy-coated $0.019 \times 0.025$-inch stainless-steel archwires from different companies immersed in Miranda ${ }^{\circledR}$ for different time intervals using a visible spectrophotometer. She found that Miranda ${ }^{\circledR}$ had a minimal coloring effect on all the tested brands owing to the cleaning effect of its acidic contents (i.e., ascorbic and citric acids). 


\section{Effects on Elastics' Force Decay}

Nattrass et al. ${ }^{43}$ evaluated the effect of Coca-Cola ${ }^{\circledR}$ at different temperatures on the force delivered by the elastomeric power chain from Ortho-Care over different time intervals. They concluded that temperature, $\mathrm{pH}$, and composition of Coca-Cola ${ }^{\circledR}$ had a great effect on the force decay of the elastomeric chain than distilled water.

Teixeira et al. ${ }^{44}$ conducted an in vitro study to assess the effect of DietCoke ${ }^{\circledR}$, phosphoric acid, and citric acid ( $\left.\mathrm{pH}=2.60\right)$ on the force decay of 2 types of elastomeric power chains immersed for 15 minutes twice daily over 3 weeks. They found a significant decline in the force of both elastomeric chains in the first 24 hours with no significant difference per the immersion media.

Hemed $^{45}$ evaluated the effect of Pepsi-Cola ${ }^{\circledR}$ on the remaining force of different types of elastomeric power chains immersed once daily for 8 minutes over 4 weeks. She found that Pepsi-Cola ${ }^{\circledast}$ decreased the remaining force over the 4-week period compared with the control group.

140 Leão Filho et al. $^{46}$ tested the force degradation effects of immersing $1 / 4$ inch intermaxillary elastics in Coca-Cola ${ }^{\circledR}$ and artificial saliva (as a control). The immersion took place in 5 cycles. In the $1{ }^{\text {st }}$ and $2{ }^{\text {nd }}$ cycles, the elastics were immersed for 15 minutes in the tested beverages and were then immersed for 3 mintues in the artificial saliva. In the $3^{\text {rd }}, 4^{\text {th }}$, and $5^{\text {th }}$ cycle, the immersion lasted for 30 minutes followed by 3 minutes of immersion in artificial saliva. The results indicated that Coca-Cola ${ }^{\circledR}$ did not affect the force degradation of the tested elastics compared with the artificial saliva; hence, the chemical nature of Coca-Cola ${ }^{\circledR}$ had no additional effect.

Teixeira et al. ${ }^{44}$ demonstrated that immersion in Diet Coke ${ }^{\circledR}$ was not able to alter the pattern of force degradation in 2 different types of elastomeric chains, in agreement with Leão Filho et al. ${ }^{46}$ who found that diet beverages did not affect the force degradation of the tested elastics compared with artificial saliva; hence, the chemical nature of these beverages had no effect, unlike the findings from a study by Hemed ${ }^{45}$. One of the drawbacks of the study by Teixeira et al. was that they did not measure the $\mathrm{pH}$ of the tested beverages.

Pithon et al. ${ }^{47}$ investigated the effect of Coca-Cola ${ }^{\circledR}$, Fanta ${ }^{\circledR}$, Guarana Antarctica ${ }^{\circledR}$, and Sprite $^{\circledR}$ on force decay in elastomeric chains in comparison with de-ionized water and artificial saliva. They immersed the chains in the soft drinks twice daily for 3 minutes with an interval of 6 hours between the exposures for over 6 intervals. They found that the $\mathrm{pH}$ of acidic substances, preservatives, pigments, chlorides, and phosphates had an effect on the elastic decay in (in decreasing order) Coca-Cola ${ }^{\circledR}$, Fanta ${ }^{\circledR}$, Guarana Antarctica ${ }^{\circledR}$, and Sprite ${ }^{\circledR}$ but with less influence than the artificial saliva.

Aldrees et al. ${ }^{37}$ compared the percentage of force decay in clear and semi-clear elastomeric chains from 8 manufacturers after immersion in Pepsi-Cola ${ }^{\circledR}$ for 72 hours. They found significant differences in the mean percentage of force decay between the clear elastomeric chain types.
Yuwana et al. ${ }^{48}$ evaluated the effect of Coca-Cola ${ }^{\circledR}$, Pepsi-Cola ${ }^{\circledR}$, and $\mathrm{BIG} \mathrm{Cola}{ }^{\circledR}$ on the tensile strength of 1/4- inch, 4.5-oz orthodontic elastic immersed in each beverage for 90 seconds per day before being immersed in artificial saliva for 24 hours and 48 hours. The results indicated that these beverages increased force decay compared with artificial saliva with no significant differences among the tested beverages.

Barretto et al. ${ }^{49}$ assessed the tensional strength of elastomeric chains immersed twice daily for 30 seconds in Coca-Cola ${ }^{\circledR}$ and cold water (at $5^{\circ} \mathrm{C} \pm 1^{\circ} \mathrm{C}$ ) compared with artificial saliva. They found that the tensional strength decreased over time and appeared to decrease more with cold water, indicating that the temperature rather than the composition of the beverage was the predominant contributing factor. This is the only study that considered the temperature of the beverages, and the exposure time was very short ( 30 seconds per day), as in vivo intake of water may change according to one's needs and the climate.

Suprayugo et al. ${ }^{50}$ investigated the effect of Coca-Cola ${ }^{\circledR}$ on the force decay of elastomeric chains over 1, 24, 42, 72, 168, and 336 hours of immersion compared with distilled water. They found a significant reduction in the force levels with no significant effect of acidity or duration of immersion in these solutions. The drawbacks of this study were that the duration of immersion was too long and that the researchers used the same pieces of elastic over the period of study, which may have led to errors because of frequent extensions during the measuring procedures.

Sallam et al. ${ }^{51}$ assessed the effect of some carbonated drinks (diet and regular Pepsi ${ }^{\oplus}$ ) on the force decay of 2 types of short elastomeric chains and concluded that carbonated drinks revealed an increased capability to affect the force decay of the orthodontic elastomeric chains than that shown by the salivary medium.

In summary, the type, configuration, and method of manufacturing should be taken into consideration along with the content, $\mathrm{pH}$, and temperature of the carbonated soft drinks.

\section{CONCLUSION}

- Increased consumption of carbonated soft drinks causes deleterious effects on the general health.

- Tooth movement is greatly affected with the increased use of carbonated soft drinks.

- Carbonated soft drinks have a great influence on the shear bond strength and enamel surface as well as the color stability of different materials.

- There are controversies regarding the effect of carbonated soft drinks on force degradation in different orthodontic elastics.

- $\quad$ Release of ions from orthodontic wires and corrosion with surface changes are obvious with the increased consumption of carbonated soft drinks.

Peer-review: Externally peer-reviewed.

Author Contributions: Supervision - M.N.; Design - M.N.; Concept - M.N.; Resources - Z.A.; Materials - Z.A., M.N.; Data Collection and/or 
Processing - Z.A., M.N.; Analysis and/or Interpretation - M.N.; Literature Search - M.N., Z.A.; Writing Manuscript -Z.A., M.N.; Critical Review -M.N.

Conflict of Interest: The authors have no conflict of interest to declare.

Financial Disclosure: The authors declared that this study has received no financial support.

\section{REFERENCES}

1. Vartanian LR, Schwartz MB, Brownell KD. Effects of soft drink consumption on nutrition and health: A systematic review and meta-analysis. Am J Public Health. 2007;97(4):667-675. [Crossref]

2. Amato D, Maravilla A, Montoya C, Gaja O, Revilla C, Guerra R, et al. Acute effects of soft drink intake on calcium and phosphate metabolism in immature and adult rats. Rev Invest Clin. 1998;50:185-189.

3. Kregiel D. Health safety of soft drinks: contents, containers, and microorganisms. Biomed Res Int 2015;2015:128697:15. [Crossref]

4. Abu-Reidah IM. Carbonated Beverages. Galanakis CM, editor. Trends in non-alcoholic beverages. 1st ed. London: Academic press, Elsevier; 2020. pp.1-36. [Crossref]

5. Vartanian LR, Schwartz MB, Brownell KD. Effects of soft drink consumption on nutrition and health: A systematic review and meta-analysis. Am J Public Health. 2007;97(4):667-75. [Crossref]

6. Aghili HA, Hoseini SM, Yassaei S, Fatahi meybodi SA, Zaeim MHT, Moghadam MG. Effects of carbonated soft drink consumption on orthodontic tooth movements in rats. J Dent (Tehran). 2014;11:123130.

7. Calvo MS. Dietary phosphorus, calcium metabolism and bone. $J$ Nutr. 1993;123(9):1627-1633. [Crossref]

8. Fitzpatrick L, Heaney RP. Got soda? J BoneMiner Res. 2003;18(9):15701572. [Crossref]

9. Paldanius $\mathrm{P}$, Ivaska $\mathrm{K}$, Hovi $\mathrm{P}$, et al. The effect of oral glucose tolerance test on serum osteocalcin and bone turnover markers in young adults. Calcif Tissue Int. 2012;90(2):90-95. [Crossref]

10. Lee SW, Russell J, Avioli LV. 25-hydroxycholecalciferol to 1, 25-dihydroxycholecalciferol: Conversion impaired by systemic metabolic acidosis. Science. 1977;195(4282):994-996. [Crossref]

11. Heaney RP, Rafferty K. Carbonated beverages and urinary calcium excretion. Am J Clin Nutr. 2001;74(3):343-347. [Crossref]

12. Massey LK, Whiting SJ. Caffeine, urinary calcium, calcium metabolism and bone. J Nutr. 1993;123(9):1611-1614. [Crossref]

13. Wink CS, Rossowska MJ, Nakamoto T. Effects of caffeine on bone cells and bone development in fast-growing rats. Anat Rec. 1996;246:30-38. [Crossref]

14. Shirazi M, Vaziri H, Salari B, Motahhari P, Etemad-Moghadam S, Dehpour AR. The effect of caffeine on orthodontic tooth movement in rats. Iran J Basic Med Sci. 2017;20:260-264.

15. Oncag G, Tuncer AV, Tosun YS. Acidic soft drinks effects on the shear bond strength of orthodontic brackets and a scanning electron microscopy evaluation of the enamel. Angle Orthod. 2005;75:247-253.

16. Navarro R, Vicente A, Ortiz AJ, Bravo LA. The effects of two soft drinks on bond strength, bracket microleakage, and adhesive remnant on intact and sealed enamel. Eur J Orthod. 2011;33(1):60-65. [Crossref]

17. Khoda OM, Heravi F, Shafaee H, Mollahassani H. The effect of different soft drinks on the shear bond strength of orthodontic brackets. J Dent (Tehran). 2012;9:145-149.

18. Hammad SM, Enan ET. In vivo effects of two acidic soft drinks on shear bond strength of metal orthodontic brackets with and without resin infiltration treatment. Angle Orthod. 2013;83(4):648-652. [Crossref]

19. Nahidh M. The effects of various beverages on the shear bond strength of light-cured orthodontic composite (An in vitro comparative study). J Bagh Coll Dentistry. 2014;26(3):144-148. [Crossref]

20. Pasha A, Sindhu D, Nayak RS, Mamatha J, Chaitra KR, Vishwakarma S. The effect of two soft drinks on bracket bond strength and on intact and sealed enamel: An in vitro study. J Int Oral Health. 2015;7:26-33.
21. Rugg-Gunn AJ, Maguire A, Gordon PH, McCabe JF, Stephenson G. Comparison of erosion of dental enamel by four drinks using an intra-oral appliance. Caries Res. 1998;32(5):337-343. [Crossref]

22. Waterhouse PJ, Auad SM, Nunn JH, Steen IN, Moynihan PJ. Diet and dental erosion in young people in south-east Brazil. Int J Paediatr Dent. 2008;18(5):353-360. [Crossref]

23. Örtengren $\mathrm{U}$, Wellendorf $\mathrm{H}$, Karlsson S, Ruyter IE. Water sorption and solubility of dental composites and identification of monomers released in an aqueous environment. J Oral Rehabil. 2001;28(12):11061115. [Crossref]

24. Nishiyama N, Suzuki K, Yoshida H, Teshima H, Nemoto K. Hydrolytic stability of methacrylamide in acidic aqueous solution. Biomaterials. 2004;25(6):965-969. [Crossref]

25. Shahabi M, Jahanbin A, Esmaily $H$, Sharifi $H$, Salari S. Comparison of some dietary habits on corrosion behavior of stainless steel brackets: An in vitro study. J Clin Pediatr Dent. 2011;35(4):429-432. [Crossref]

26. Parenti SI, Guicciardi S, Melandri C, et al. Effect of soft drinks on the physical and chemical features of Nickel-Titanium-based orthodontic wires. Acta Odontol Scand. 2012;70(1):49-55. [Crossref]

27. Abalos C, Paul A, Mendoza A, Solano E, Palazon C, Gil FG. Influence of soft drinks with low $\mathrm{pH}$ on different $\mathrm{Ni}$-Ti orthodontic archwire surface patterns. J Mater Eng Performance. 2013;22:759-766. [Crossref]

28. Mikulewicz M, Wołowiec P, Loster BW, Chojnacka K. Do soft drinks affect metal ions release from orthodontic appliances? J Trace Elem Med Biol. 2015;31:74-77. [Crossref]

29. Kim H, Johnson JW. Corrosion of stainless steel, Nickel-Titanium, coated Nickel-Titanium, and Titanium orthodontic wires. Angle Orthod. 1999;69:39-44.

30. Nanjundan K, Vimala G. Evaluation of frictional resistance and surface characteristics after immersion of orthodontic brackets and wire in different chemical solutions: A comparative in vitro study. Indian J Dent Res. 2016;27(5):513-520. [Crossref]

31. Alavi S, Barooti S, Borzabadi-Farahani A. An in vitro assessment of the mechanical characteristics of Nickel-Titanium orthodontic wires in Fluoride solutions with different acidities. J Orthod Sci. 2015;4(2):52-56. [Crossref]

32. Kao CT, Huang TH. Variations in surface characteristics and corrosion behaviour of metal brackets and wires in different electrolyte solutions. Eur J Orthod. 2010;32(5):555-560. [Crossref]

33. Lew KKK. Staining of clear elastomeric modules from certain foods. J Clin Orthod. 1990;24:472-74.

34. Al-Huwaizi AF, Kalhan HF. Stainability of clear overlay retainers after immersion in different drinks. Iraqi Orthod J. 2007;3:1-7.

35. Ardeshna AP, Vaidyanathan TK. Colour changes of orthodontic elastomeric module materials exposed to in vitro dietary media. $J$ Orthod. 2009;36(3):177-185. [Crossref]

36. Silva LK, Guignone BC, Marinho KC, et al. In vitro evaluation of color changes of aesthetic orthodontic elastic ligatures. Int J Odontostomat. 2014;8(3):399-403. [Crossref]

37. Aldrees AM, Al-Foraidi SA, Murayshed MS, Almoammar KA. Color stability and force decay of clear orthodontic elastomeric chains: An in vitro study. Int Orthod. 2015;13(3):287-301. [Crossref]

38. Guignone BC, Silva LK, Soares RV, Akaki E, Goiato MC, Pithon MM, et al. Color stability of ceramic brackets immersed in potentially staining solutions. Dental Press J Orthod. 2015;20(4):32-8. [Crossref]

39. Albo Hassan AF, Ghaib NH. Effect of different staining materials on color stability of sapphire brackets bonded with different types of light cure orthodontic adhesives (An in vitro study). J Bagh Coll Dentistry. 2015;27(2):136-141. [Crossref]

40. Talic NF, Almudhi AA. The effect of dietary pigmentation on the esthetic appearance of clear orthodontic elastomeric modules. $J$ Orthod Sci. 2016;5(2):70-73. [Crossref]

41. Noori ZT, Ghaib NH. Color stability of different aesthetic archwires (An In vitro study). J Bagh Coll Dentistry. 2016;28:164-168. [Crossref]

42. Mahmood AB. Color stability of coated stainless steel arch wires measured by visible spectrophotometer (An in-vitro study). J Global Pharma Technol. 2018;10:149-153. 
43. Nattrass C, Ireland AJ, Sherriff M. The effect of environmental factors on elastomeric chain and Nickel Titanium coil springs. Eur J Orthod. 1998;20(2):169-176. [Crossref]

44. Teixeira L, Pereira BR, Bortoly TG, Brancher JA, Tanaka OM, Guariza-Filho O. The environmental influence of Light Coke, phosphoric acid, and citric acid on elastomeric chains. J Contemp Dent Pract. 2008;9(7):17-24. [Crossref]

45. Hemed BM. The effect of drinks and food simulants on the force applied by orthodontic elastomeric chains (An experimental in vitro study). A master thesis. Department of Orthodontics, College of Dentistry, University of Baghdad, 2008.

46. Leão Filho JCB, Gallo DB, Santana RM, Guariza-Filho O, Camargo ES, Tanaka OM. Influence of different beverages on the force degradation of intermaxillary elastics: An in vitro study. J Appl Oral Sci. 2013;21(2):145-149. [Crossref]

47. Pithon MM, Lacerda-Santos R, Santana LR, Rocha M, Leal RO, Santos $\mathrm{MM}$. Does acidic drinks vs. controls different interfere with the force of orthodontic chain elastics? Biosci J Uberlândia. 2014;30:19521958.

48. Yuwana $\mathrm{CP}$, Christnawati, Farmasyanti $\mathrm{C}$. The effect of immersion time in three kinds of carbonated beverages on orthodontic elastic latex's tensile strength (In-Vitro). UIP Health Med. 2016;1:63-67. [Crossref]

49. Barretto P, Souza G, Ferraz C, Pithon M, Machado AW, Braga E. Experimental evaluation of strength degradation of orthodontic chain elastics immersed in Cola beverage. Acta Scientific Dent Sci. 2018;2:35-39.

50. Suprayugo M, Eriwati YK, Santosa AS. Effect of $\mathrm{pH}$ of soft drinks on force decay in orthodontic power chains. IOP Conf. Series: J Phy: Conf Ser. 2018;1073(6):1-6. [Crossref]

51. Sallam SM, Ramadan AA, Elgamy WE. Effect of some carbonated drinks on force decay of elastomeric chains: An in vitro study. Egyp Orthod J. 2018;53:31-389. [Crossref] 